\title{
Manajemen sistem informasi $e$-budgeting pada Sekolah Menengah Atas Negeri di Kota Yogyakarta
}

\author{
Aan Yudha Nugraha *, Udik Budi Wibowo \\ Pascasarjana, Universitas Negeri Yogyakarta. \\ Jl. Colombo No. 1, Karang Malang, Depok, Sleman, Daerah Istimewa Yogyakarta 55281, Indonesia. \\ aanynugraha@gmail.com \\ * Corresponding Author
}

\section{ARTICLE INFO}

\section{Article History}

Received:

10 March 2020;

Revised:

27 July 2020;

Accepted:

31 July 2020

\section{Keywords}

Manajemen;

Pembiayaan

pendidikan;

Sistem informasi;

E-budgeting;

Management,

Education funding;

Information systems

\begin{abstract}
Penelitian ini bertujuan untuk: 1.) Mendeskripsikan mengenai manajemen sistem informasi (SI) e-budgeting di Sekolah Menengah Atas Negeri (SMAN) di Kota Yogyakarta; dan 2.) Menganalisis keunggulan dan hambatan dalam manajemen SI $e$ budgeting di SMAN di Kota Yogyakarta. Penelitian ini merupakan penelitian kualitatif dengan jenis studi kasus. Penelitian dilaksanakan di SMAN di wilayah Kota Yogyakarta. Subjek penelitian meliputi kepala sekolah, bendahara dan admin ebudgeting. Penelitian juga dilakukan pada Dinas Pendidikan Pemuda dan Olahraga, Balai Pendidikan Menengah Kota Yogyakarta, dan Dinas Pendidikan Kota Yogyakarta. Data dikumpulkan melalui teknik wawancara, observasi dan studi dokumen. Analisis data menggunakan model analisis data Creswell. Teknik keabsahan data penelitian menggunakan teknik triangulasi dan menggunakan bahan referensi. Hasil penelitian menunjukkan sistem e-budgeting baru diterapkan pada jenjang SMAN sederajat. Perencanaan mengikuti pola penyusunan RKAS. Pengorganisasian meliputi pengerahan staf dan adanya pelatihan. Sistem ini berfungsi untuk mengelola dana BOS dan APBD. Pengawasan dilakukan oleh kepala sekolah dan dinas terkait. Terdapat keunggulan dan hambatan dalam implementasi $e$ budgeting. E-budgeting berperan dalam meningkatkan transparansi dan akuntabilitas pembiayaan pendidikan.
\end{abstract}

This study aims to: 1.) Describe the management of information systems (IS) ebudgeting at State High Schools (SMAN) in Yogyakarta City; and 2.) Analyze the advantages and obstacles in the management of SI e-budgeting at SMAN in Yogyakarta City. This research is a qualitative study with a case study type. This research was conducted at SMAN in the Yogyakarta City area. Research subjects include the principal, treasurer, and admin e-budgeting. The research was also conducted at the Youth and Sports Education Office, Yogyakarta City Secondary Education Center, and the Yogyakarta City Education Office. Data collected through interview techniques, observation, and study of documents. Data analysis uses Creswell's data analysis model. The validity of the research data using triangulation techniques and using reference materials. The results showed that the new ebudgeting system was applied at the same level of high school. Planning follows the RKAS preparation pattern. Organizing includes staff deployment and training. This system functions to manage BOS and APBD funds. Supervision is carried out by principals and related agencies. There are advantages and obstacles in implementing e-budgeting. E-budgeting plays a role in increasing transparency and accountability in education funding.

This is an open access article under the $\underline{\mathrm{CC}-\mathrm{BY}-\mathrm{SA}}$ license.

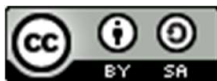

How to cite:

Nugraha, A. Y., \& Wibowo, U. B. (2020). Manajemen sistem informasi e-budgeting pada Sekolah Menengah Atas Negeri di Kota Yogyakarta. Jurnal Akuntabilitas Manajemen Pendidikan, 8(1), 70-80.

doi:https://doi.org/10.21831/jamp.v8i1.30596 


\section{PENDAHULUAN}

Sekolah sebagai salah satu tempat penyelenggaraan pendidikan tentunya perlu memperhatikan beberapa komponen, antara lain: sarana prasarana, tenaga pendidik, kurikulum, peserta didik, dan pembiayaan dalam kegiatan belajar mengajar, budaya sekolah yang semuanya saling terkait dalam penyelenggaraan pendidikan. Komponen-komponen tersebut sangat penting dan saling berpengaruh sehingga dapat memberikan kontribusinya terhadap pencapaian tujuan pendidikan. Sebuah lembaga pendidikan yang bermutu tidak terlepas dari keadaan pembiayaan pendidikan di dalamnya, karena pada dasarnya mutu pendidikan berbanding lurus dengan biaya pendidikan yang dikeluarkan (Nasori, 2019, p. 119). Pembiayaan pendidikan yang baik adalah pembiayaan yang mampu memenuhi semua kebutuhan berdasarkan anggaran yang telah dibuat. Untuk dapat memenuhi kebutuhan sesuai anggaran yang telah dibuat diperlukan kemampuan mengelola yang baik. Pembiayaan pendidikan pada dasarnya merupakan suatu proses mengalokasikan sumber-sumber pada program dan kegiatan operasional pendidikan atau dalam proses belajar mengajar di kelas. Hal-hal yang berkaitan dengan pembiayaan pendidikan meliputi; pelaksanaan anggaran pendidikan, akuntansi dan pertanggungjawaban keuangan pendidikan, serta pemeriksaan dan pengawasan anggaran pendidikan (Matin, 2014, p. 4).

Anggaran operasional sekolah merupakan aspek yang masih diperdebatkan antara pihak pengelola sekolah dengan pemangku kepentingan (stakeholders). Di satu sisi, pengelola sekolah merasa dana pendidikan masih kurang, oleh karena itu pihak sekolah masih melakukan pungutan dana kepada orang tua siswa. Dalam Kompas (16 Oktober 2018) disebutkan dalam menanggapi keluhan masyarakat tentang penggunaan dana sekolah, termasuk dana bantuan operasi sekolah (BOS) dari pemerintah, Mendiknas meminta dana sekolah dikelola secara transparan. Khoirunnisak, Arishanti, dan Vebrianti (2017) berpendapat bahwa:

"penyelewengan juga dapat akibat harga satuan item belanja yang tidak terstandar, terjadinya budget maximizing yang pada akhirnya dapat menyebabkan inefisiensi, proses penganggaran yang tidak transparan dan tidak adanya kejelasan rincian dana, rekap anggaran per-rekening belanja tidak real time, serta masalah yang muncul akibat masih mengandalkan pertemuan face-to-face".

Fenomena globalisasi dan modernisasi, yang disertai dengan meningkatnya tuntutan masyarakat akan pemenuhan kebutuhan pendidikan yang baik dan berkualitas. Hal ini membuat pemerintah harus mampu beradaptasi dengan lingkungan internal maupun eksternal untuk menanggapi tuntutan-tuntutan masyarakat secara efektif dan efisien. Namun pada kenyataannya, pemenuhan tuntutan publik masih menemui banyak permasalahan, terutama di sekolah yang masih tetap saja ada sekolah melakukan pungutan-pungutan dengan berbagai dalih dan ketidaktahuan batasan atas larangan yang dimaksud dalam aturan. Hal ini salah satunya diakibatkan oleh proses penyelenggaraan pemerintahan dan pendistribusian pelayanan pendidikan yang tidak transparan, sehingga banyak menciptakan peluang terjadinya korupsi.

Teknologi menjadi pendukung di bidang pendidikan dengan contoh berbagai perangkat elektronik dan perangkat lunak pendidikan yang berkembang pesat saat ini. Dengan keberadaan teknologi ini banyak pengurangan biaya perangkat keras dan perangkat lunak telah di aplikasikan di sekolah-sekolah, dan mendukung education for all. Pada saat yang sama, dalam Earthman (2009, p. 229) mengemukakan bahwa penerapan teknologi yang terbaru dan terinovasi ke semua sekolah, telah menjadi hal utama yang perlu dipertimbangkan oleh para pendidik dan anggota dewan sekolah. Salah satu inovasi dan juga pengembangan sistem informasi dibidang pendidikan adalah dengan adanya $e$ budgeting yang membantu dalam sistem penganggaran.

Bentuk sistem informasi e-budgeting terlihat dari pemaparan pada penelitian Zarnelly (2017, p. 75) yang menyebutkan bahwa e-budgeting mengacu pada pengertian sistem informasi sebagai suatu kombinasi dari people (orang), hardware (perangkat keras), software (piranti lunak), computer netwiorks and data communication (jaringan komunikasi), data base (basis data) yang mengumpulkan, mengubah, dan menyebarkan informasi bagi pengguna dalam suatu organisasi. Dari bentuk sistem e-budgeting itu, sistem ini merupakan perpaduan kinerja dari manusia dan komputer yang dapat membantu mengelola proses penganggaran pendanaan pada suatu organisasi. Sistem ini dapat 
membantu pekerjaan pengelolaan anggaran mulai dari proses input hingga menampilkan laporan anggaran. Pembiayaan pendidikan dan sistem informasi, kedua hal tersebut tentu memerlukan sebuah sistem pengelolaan yang baik. Dalam organisasi pendidikan membutuhkan manajemen dalam setiap jenis penyelenggaraan dan pengelolaannya. Definisi manajemen menurut Anoraga (2009, p. 109) adalah seni untuk mencapai hasil yang maksimal dengan usaha yang minimal (dengan metode yang efesien dan efektif), demikian pula mencapai kesejahteraan dan kebahagiaan maksimal baik bagi pimpinan maupun para pekerja serta memberikan pelayanan sebaik mungkin kepada masyarakat.

Cara pengelolaan biaya disebut dengan manajemen pembiayaan. Menurut Arwildayanto, Nina, dan Warni (2017, p. 24) adapun tahapan dalam manajemen pembiayaan yaitu; penyusunan perencanaan anggaran (budgeting), pembukuan (accounting), dan pemeriksaan (auditing). Budgeting merupakan proses mengidentifikasi tujuan, menetapkan prioritas, mendeskripsikan tujuan ke dalam tampilan operasional yang dapat diukur, menganalisis alternatif pencapaian tujuan, serta membuat rekomendasi alternatif untuk mencapai sasaran tersebut. Accounting merupakan kegiatan pembukuan meliputi dua hal, yaitu: 1.) Pengaturan yang menyangkut akan hal kewenangan dalam menentukan kebijakan tentang menerima dan mengeluarkan uang; dan 2.) Pengaturan tentang bagaimana tata cara menerima, menyimpan serta mengeluarkan uang. Auditing merupakan proses yang menyangkut mengenai pertanggungjawaban penerimaan, penyimpanan dan pembayaran atau penyerahan uang. Pemeriksaan pembiayaan pendidikan terdiri dari kegiatan memonitor, menilai, dan melaporkan yang merupakan kegiatan yang bersifat sistematis. Menurut Matin (2014, p. 188) jika dilihat dari perspektif pelaksanaan pengawasan, pengawasan penggunaan anggaran pendidikan dapat dikategorikan kedalam empat kelompok, yaitu: 1.) Pengawasan melekat (waskat); 2.) Pengawasan fungsional (wasnal); 3.) Pengawasan legislatif; dan 4.) Pengawasan masyarakat (wasmas).

Implementasi anggaran di organisasi pendidikan seperti sekolah, mendapati beberapa permasalahan yang umum terjadi seperti sistem pengalokasian, persaingan dalam sumber daya, dan lagi dikarenakan pemerintah bukan hanya melayani beberapa sekolah, melainkan juga banyak ragam dan jenis sekolah lainnya. Masalah selanjutnya bagi sekolah adalah selalu lebih banyak kebutuhan untuk dilayani daripada dana untuk melayani mereka. Dari sini lah dituntut untuk bagaimana sekolah dapat bijak dan akuntabel dalam menetapkan prioritas untuk memilih kegiatan yang akan didanani atau tidak didanai. Sekolah dalam menjalankan fungsi dan kewajibannya, yaitu menyelenggarakan proses pembelajaran yang sesuai dengan tuntutan zaman dan ekpektasi serta harapan dari konsumen pendidikan (siswa dan orang tua siswa) tentu membutuhkan pendanaan dalam menjalankan proses pembelajaran maupun operasionalnya sebagai pendukung.

Lunenburg dan Ornstein (2000) megungkapkan bahwa pembiayaan pendidikan merupakan masalah utama penyelenggaraan pendidikan di USA. Pada awal tahun 1930-an pemerintah lokal menanggung sekitar 82,7\% biaya pendidikan. Pada tahun 1999 proporsi pembiayaan bergeser menjadi pemerintah federal (pusat) sebesar 6,1\%, negara bagian sebesar 43,9\%, pemerintah lokal sebesar 39,9\%, dan sumber lain sebesar 10,2\%. Namun, besar dana yang disediakan bervariasi antar negara bagian, misalnya di New Jersey sebesar US\$ 9.318 dan di Utah US\$3.670/siswa/tahun. Disini terlihat bahwa bagaimana USA mengelola dana pendidikan, karena dana pendidikan bukan hanya tanggungjawab pemerintah pusat, tapi juga memberlakukan sistem desentralisasi dana pendidikan dengan membebankan beberapa persen dari total anggaran kepada negara bagian untuk mendanai pendidikan daerahnya.

Dari berbagai macam tantangan dan hambatan dalam pembiayaan pendidikan di sekolah, seperti, besaran ketersediaan dana, prioritas anggaran, sistem penganggaran yang dapat menampilkan hasil program, tujuan, dan umpan balik. Tantangan pembiayaan juga didasarkan kepada bagaimana cara untuk memenuhi prinsip pembiayaan yang efektif, efisien, transparan dan akuntabel. Maka dari itu, dibutuhkan sebuah sistem yang dapat membantu dalam hal manajerial, informasi yang tepat sasaran dan tepat waktu, yaitu dengan adanya Sistem Informasi (SI) dalam pengelolaan dana pendidikan yaitu e-budgeting. Sebuah sistem modern peningkatan dari sistem pengelolaan dana pendidikan secara konvensional yang selama ini berjalan. Sistem informasi (SI) adalah sebuah sistem pengguna mesin yang terintegrasi, terkomputerisasi dan menyediakan informasi yang diperlukan untuk mendukung operasi organisasi. Menurut Awad (dalam Babaei \& Beikzad, 2013, p. 375) elemen utama dari sistem informasi adalah: 1.) Sistem terintegrasi untuk memberikan layanan kepada banyak pengguna; 2.) Sistem komputer menghubungkan beberapa perangkat lunak informasi melalui 
database; 3.) Interface pengguna-mesin merespons pencarian sementara dan segera; 4. Mempresentasikan informasi ke semua level manajemen; dan 5.) Mendukung operasi dan kinerja organisasi.

Qadriyanti (2013, p. 83) menyebutkan bahwa kemajuan teknologi pada telekomunikasi dan teknologi informasi pada akhirnya menjadikan perubahan terhadap tatanan organisasi dan hubungan sosial dan kemasyarakatan. Hal ini menimbulkan suatu perubahan dalam aktivitas kehidupan masyarakat dalam berbagai sektor. Perkembangan teknologi informasi dan komunikasi dapat melahirkan model pelayanan publik yang dilakukan melalui electronic system. Bagaimanapun hal ini harus diterima oleh setiap organisasi agar dapat bertahan dan bersaing. Banyak keuntungan pelayanan yang dilakukan menggunakan teknologi dan electronic system, seperti: layanan menjadi lebih cepat, real time, dapat diakses kapan dan dimana saja, serta lebih transparan. Telah banyak teknologi dan sistem elektronik yang diterapkan di bidang pendidikan, contohnya adalah kondisi sekarang dimana teknologi tersebut telah diterapkan pada manajemen pembiayaan di sekolah, yaitu dengan penerapan e-budgeting pada proses manajemen pembiayaan di sekolah, yang notabene proses tersebut sebelumnya (meliputi pencatatan, pelaporan dan pertanggungjawaban) selama ini dilakukan secara konvensional atau pencatatan manual. Dengan hadirnya teknologi ini diharapkan dapat membantu serta mempermudah pihak terkait dalam hal manajemen pembiayaan pendidikan.

Dari bagian manajemen ini, dikelompokkan kedalam fungsi-fungsi yang dilakukan pada saat menjalankan manajemen itu sendiri. Adapun fungsi manajemen menurut Terry dan Rue (2010, p. 43), yaitu: 1.) Perencanaan (planning); 2.) Pengorganisasian (organizing); 3.) Pelaksanaan (actuating); dan 4.) Pengawasan (controlling). Planning merupakan suatu proses pembuatan tujuan tentang apa-apa saja yang akan menjadi target oleh lembaga atau organisasi selama suatu jangka waktu tertentu yang akan datang, serta melakukan persiapan dengan menyediakan berbagai macam perangkat, agar tujuan yang ingin dicapai dapat tercapai dengan baik. Organizing merupakan upaya kerjasama untuk melibatkan banyak personel yang berkompeten dalam bidangnya untuk mencapai tujuan, sehingga pengorganisasian akan membuat setiap personel paham tentang tigas pokok dan fungsinya masing-masing. Actuating merupakan salah satu dari fungsi manajemen yang dapat dimaknai sebagai cara manajemen untuk mewujudkan segala rencana agar tercapai tujuan organisasi melalui pengerahan, pemanfaatan, dan pengarahan semua sumber daya dalam organisasi tersebut. Fungsi pengawasan mutlak diperlukan dalam berjalannya suatu sistem manajemen suatu organisasi. Menurut Matin (2014, p. 185) pengawasan (controlling) merupakan suatu kegiatan melihat, memerhatikan, memonitor, memeriksa, menilai, dan melaporkan pelaksanaan suatu program kerja yang telah direncanakan sebelumnya dengan tujuan agar kegiatan-kegiatan yang telah direncanakan dan atau dilaksanakan sesuai dengan persyaratan yang ada dalam perencanaan.

Pengawasan penggunaan anggaran pendidikan tidak lepas dari konsep efisiensi dan efektivitas pelaksanaan rencana dan program pendidikan, efisiensi merujuk kepada suatu rasio antara masukan dan keluaran, hanya jika sistem tersebut menghasilkan keluaran yang cukup atau bahkan lebih dari yang ditargetkan dengan menggunakan sumber daya yang minimal. Sementara efektivitas merujuk pada suatu rasio antara keluaran yang diinginkan dengan keluaran yang dicapai. Sistem informasi $e$ budgeting dapat menjadi sebuah media yang dapat menjadi perantara guna tercapainya efektivitas dan efisiensi manajemen pembiayaan. Sistem informasi keuangan sangat penting bagi stabilitas, keberlanjutan, dan pertumbuhan sebuah organisasi. Ameen dan Ahmad (2013, p. 59) dalam penelitiannya menyebutkan bahwa sejak 1984, Bank Dunia telah membiayai 87 proyek sistem informasi keuangan di 51 negara, dengan total lebih dari US \$2,2 miliar. Sebagian besar dari jumlah ini diberikan untuk solusi Teknologi Informasi dan Komunikasi (TIK) terkait sistem informasi keuangan. Sistem ini dirancang dengan fokus yang lebih baik pada kualitas, fungsionalitas, keandalan, dan kemampuan untuk mengurangi resiko korupsi.

E-budgeting merupakan sistem informasi yang digunakan untuk penyusunan anggaran guna meningkatkan efisiensi dan efektivitas dalam proses penganggaran. Sistem e-budgeting memberikan peranan yang penting dalam pembuatan anggaran. Sistem tersebut mampu mempersingkat waktu yang diperlukan dalam proses pembuatan anggaran, karena dilakukan secara online dan dapat diakses di mana saja. Sistem ini juga berfungsi sebagai alat pengawasan kerja yang dapat memantau poses dalam penyusunan anggaran. Selain itu, prosedur dalam e-budgeting juga dapat mengantisipasi potensi adanya mark-up dengan adanya sistem saling mengawasi (Pemerintak Kota Surabaya, 2017). Diharapkan dengan adanya e-budgeting ini yang diterapkan di sekolah dapat membantu dalam 
penyusunan anggaran (budgeting), pembukuan (accounting), hingga pemeriksaan (controlling), serta dampak laten negatif lain yang sering terjadi pada sistem pembiayaan seperti mark-up dan korupsi. Penelitian ini menyajikan temuan bagaimana proses manajemen sistem informasi e-budgeting di sekolah sebagai organisasi pendidikan, yang selama ini objek penelitian dilakukan organisasi profit (perusahaan) dan lembaga kepemerintahan, serta bagaimana sistem ini memiliki kelebihan dan kendala jika dijalankan pada sekolah.

\section{METODE}

Jenis Penelitian

Penelitian ini merupakan jenis penelitian yang disusun berdasarkan pendekatan kualitatif dan dengan metode studi kasus. Pendekatan kualitatif memiliki sifat sebagai berikut: deskriptif, lebih memilki latar natural, peneliti lebih memperhatikan proses daripada hasil, peneliti cenderung menganalisis data secara induktif. Sugiyono (2011, p. 289) menyebutkan bahwa metode deskriptif digunakan untuk mengeksplorasi dan atau memotret situasi sosial yang akan diteliti secara menyeluruh, luas, dan mendalam. Sedangkan menurut Yin (2010, p. 18) studi kasus merupakan studi empiris yang menyelidiki fenomena kontemporer dalam kehidupan nyata dan dimana multi sumber bukti dapat dimanfaatkan.

Waktu dan Tempat

Penelitian ini dilaksanakan di SMA Negeri yang berada di wilayah Kota Yogyakarta, Dinas Pemuda Pendidikan dan Olahraga (DIKPORA), dan Balai Pendidikan Menengah (Balai Dikmen) Kota Yogyakarta. Waktu penelitian meliputi penelitian pendahuluan yang dilakukan pada bulan Maret sampai dengan Juli 2019, pengambilan data dilakukan pada bulan Juli sampai dengan September 2019, dan analisis data dilakukan pada bulan November 2019 sampai dengan Januari 2020.

Target atau Subjek Penelitian

Subjek pada penelitian ini dibagi menjadi dua bagian, yaitu subjek yang menjadi sumber data primer antara lain: kepala sekolah, bendahara, dan admin e-budgeting, staf Dinas Pemuda Pendidikan dan Olahraga (DIKPORA), Balai Pendidikan Menengah (Balai Dikmen) Kota Yogyakarta, dan Dinas Pendidikan Kota Yogyakarta. Data sekunder meliputi dokumen mengenai struktur organisasi sekolah dan laporan penggunaan dana pendidikan di sekolah yang dikelola melalui sistem e-budgeting.

\section{Teknik Pengumpulan Data}

Teknik yang digunakan dalam pengumpulan data dari penelitian ini, menggunakan teknik pengumpulan data yaitu observasi, wawancara, dan studi dokumentasi. Observasi merupakan suatu proses pengamatan dan ingatan (Sugiyono, 2011, p. 203). Tujuan dari observasi ini adalah untuk mendapatkan informasi mengenai pemanfaatan anggaran di lingkungan sekolah tersebut. Observasi yang dilakukan peneliti meliputi hal atau kondisi yang tampak pada saat melakukan penelitian di lapangan. Pada penelitian ini teknik wawancara yang digunakan yaitu jenis wawancara baku terbuka, Moleong (2017, p. 187) menjelaskan bahwa jenis wawancara ini menggunakan seperangkat pertanyaan baku, hal ini dimaksudkan agar menghilangkan kemungkinan terjadinya kekeliruan. Studi dokumen digunakan untuk mengumpulkan data dari sumber non-insani yang terdiri dari dokumen dan rekaman. Miles dan Huberman (1992, p. 75) menjelaskan bahwa dokumen yang diperoleh pada teknik ini dapat digunakan sebagai bahan refernsi dan komparasi. Dengan analisis dokumentasi diharapkan data yang diperlukan menjadi benar-benar valid 


\section{Keabsahan Data}

Uji keabsahan data yang digunakan dalam penelitian ini adalah uji credibility. Uji kredibilitas yang diterapkan terhadap hasil penelitian ini adalah triangulasi dan menggunakan bahan referensi. Triangulasi yang digunakan pada penelitian ini adalah triangulasi sumber dan teknik. Penggunaan bahan referensi yang dimaksud dalam uji ini adalah, data dan dokumen autentik dan terpercaya yang dapat mendukung untuk membuktikan data yang telah ditemukan

\section{Analisis Data}

Analisis data menggunakan data analysis spiral yang dikemukakan oleh Creswell, pada analisis data kualitatif menggunakan model ini merupakan suatu proses penerapan langkah-langkah yang spesifik hingga umum dengan berbagai level analisis yang berbeda. Lebih lanjut Creswell (2015, p. 254) menjelaskan adapun langkah-langkah dalam menganalisis data adalah sebagai berikut: data collection, data managing, reading and memoing, describing, classify and interpreting, representing and visualizing.

\section{HASIL DAN PEMBAHASAN}

Hasil

\section{E-budgeting pada SMAN di Kota Yogyakarta}

Kebijakan pengalihan wewenang tersebut turut merubah pula pada kebijakan dan cara pengelolaan keuangan di jenjang SMA sederajat, yaitu, yang mana Dinas Pemuda Pendidikan dan Olahraga (DIKPORA) yang menaungi SMA sederajat sebelumnya memang sudah lama menggunakan sistem e-budgeting, lalu setelah itu sistem ini pula diterapkan di sekolah untuk penyeragaman, serta meningkatkan performa daripada sistem pengelolaan keuangan sekolah. Keberadaan sistem $e-$ budgeting untuk mengelola keuangan sekolah juga dibantu oleh keberadaan e-katalog dan standar harga barang dan jasa (SHBJ). E-katalog dan SHBJ (diatur dalam Peraturan Gubernur Daerah Istimewa Yogyakarta Nomor 72 Tahun 2017 tentang Standar Harga Barang dan Jasa Daerah) ini menjadi patokan dan pegangan bagi sekolah dalam menentukan harga untuk pembelanjaan barang dan jasa, sehingga untuk setiap pembelanjaan harga menjadi seragam dan masuk akal (wajar) disetiap sekolah. E-katalog dan SHBJ ini juga mendorong untuk meningkatkan aspek transparansi dan akuntabilitas penggunaan dana pendidikan di sekolah terhadap belanja barang dan jasa yang dilakukan.

\section{Perencanaan dan Penganggaran}

Proses perencaan dan penganggaran dengan menggunakan sistem e-budgeting pada SMAN Kota Yogyakarta tahap pertama yang dilakukan adalah menyusun atau membuat rencana anggaran terlebih dahulu yang direalisasikan dalam bentuk kegiatan rapat tahunan yang diadakan oleh sekolah. Waktu penyusunan rencana anggaran yang tertuang pada RKAS seperti yang dijabarkan oleh Direktorat Jenderal Pendidikan Dasar dan Menengah (2015) penyusunan RKAS dilakukan pada awal tahun ajaran untuk jangka waktu satu tahun. Kegiatan rapat penyusunan rencana kegiatan dan anggaran ini masih seperti pada saat sekolah melakukan manajemen pembiayan dengan sistem konvensional (tanpa e-budgeting), yaitu dilakukan di bulan-bulan pada akhir tahun ajaran, rencana ini disusun untuk kegiatan di tahun ajaran baru selanjutnya. Sekolah biasa melakukan proses perencanaan ini dari rentang bulan April-Juni.

Sistem informasi e-budgeting merupakan sistem yang digunakan untuk membantu mengelola dana pendidikan. Dana pendidikan bagi sekolah negeri yang utama adalah yang bersumber dari pemerintah, seperti dana Anggaran Pendapatan, dan Belanja Daerah (APBD), Bantuan Operasional Sekolah (BOS), baik itu BOS nasional (BOSNAS) yang dikeluarkan oleh pemerintah pusat, dan BOS daerah (BOSDA) yang dikeluarkan oleh pemenrintah daerah. Lalu adapula dana yang bersumber dari masyarakat, namun dana ini bersifat tidak wajib dan lebih ke sukarela, contohnya adalah sumbangan dari orang tua siswa (dana komite), dan sumbangan alumni. Namun tidak semua dana tersebut dikelola menggunakan sistem e-budgeting, hanya dana yang 
berasal dari pemerintah saja, yaitu dana APBD dan BOS (BOSNAS dan BOSDA). Hal ini dikarenakan sistem ini berasal dari pemerintah, dana tersebut juga berasal dari pemerintah, lalu harus dilaporkan kepada pemerintah dengan ataupun melalui cara yang sudah ditentukan. Sedangkan, dana yang berasal dari masyarakat tadi dikelola sendiri oleh sekolah baru nanti dipertanggungjawabkan kepada masyarakat.

\section{Pengorganisasian}

Pengorganisasian yang dimaksud disini adalah pengerahan sumber daya manusia di sekolah untuk melakukan manajemen pembiayaan menggunakan sistem e-budgeting. Hal ini dimaksudkan untuk membagi job desk dan tanggung jawab kepada personel atau staf di suatu sekolah sesuai dengan kompetensi masing-masing. Pada lingkup sekolah, yang terlibat dalam penggunaan sistem ini adalah kepala sekolah dan bendahara dan atau admin e-budgeting. Peran kepala sekolah terbatas kepada pengesah dan validator dokumen keuangan sebelum diinput dan diproses kedalam sistem $e$ budgeting, sedangkan bendahara sekolah dan admin e-budgeting, adalah orang yang menggunakan dan mengoperasikan sistem ini seutuhnya.

Dalam penggunaan sistem e-budegting ini untuk memanajemen pembiayaan pendidikan di sekolah dibutuhkan personalia ataupun staf yang bersangkutan yang memiliki spesifikasi dan kualifikasi agar pekerjaan dapat dikerjakan secara benar dan tepat. Untuk dapat memiliki spesifikasi dan kualifikasi ini maka staf (bendahara dan admin e-budgeting) membutuhkan suatu pelatihan dan bimbingan, mengingat bahwa sistem e-budgeting ini merupakan sistem yang baru di sekolah.

\section{Pelaksanaan dan Pembukuan}

Pelaksanaan dan pembukuan merupakan tahap dimana sekolah merealisasikan serta melakukan pencatatan kegiatan dari rencana yang telah dibuat. Hal ini mengacu pada RKAS yang telah dibuat pada tahap perencanaan, pelaksanaan dan pembukuan menggunakan sistem e-budgeting dilakukan setelah sekolah melakukan kegiatan dan atau pembelanjaan barang dan atau jasa. Untuk jenis anggaran yang diproses menggunakan sistem ini, sebelumnya telah sempat disinggung sebelumnya bahwa hanya dana yang bersumber dari pemerintah saja, yaitu dana BOS (BOSDA dan BOSNAS) dan APBD. Hal ini berkaitan dengan bagaimana cara mempertanggungjawabkan dana tersebut kepada pemerintah dari banyak sekolah dengan pola, cara dan laporan yang seragam, sehingga mudah untuk dipahami oleh pihak terkait karena memiliki standar yang sama.

Dalam setiap pengimplementasian kebijakan dan sistem baru pada lembaga dan organisasi pasti menemukan adanya hambatan. Dibutuhkan penanganan dan solusi yang tepat untuk mengatasi hambatan tersebut, agar kedepannya bisa menjadi perbaikan dan meningkatkan performa dan kinerja bagi lembaga atau organisasi tersebut. Berikut adalah beberapa hambatan beserta solusinya dalam pengimplementasian e-budgeting di SMA Negeri: 1.) Terdapat penamaan anggaran dan kegiatan yang mirip atau hampir sama pada pilihan menu di sistem; 2.) Terdapat sistem deadline yang dirasakan membuat sekolah menjadi tidak fleksibel; 3.) Jaringan yang tidak lancar pada saat tanggaltanggal deadline pengiriman laporan; 4.) Keterbatasan SDM untuk pengoperasian sistem ini, dari segi jumlah dan skill. Solusinya adalah, jika setiap sekolah telah memiliki minimal satu bendahara, jika perlu dilakukan pengadaan atau pengangkatan untuk admin e-budgeting yang bisa berasal dari PTT (pegawai tidak tetap); 5.) Dokumen yang dibutuhkan lebih banyak untuk penggunaan dana dengan nominal tertentu; 6.) Pengharusan menggunakan satu bank (bank BPD) yang sama untuk setiap transaksi dan pembayaran; dan 7.) Pada lingkup Dinas Pemuda Pendidikan dan Olahraga (DIKPORA), sistem ini belum terintegrasi secara otomatis kedalam sistem keuangan DIKPORA, yang mana sistem ini sudah bersifat internet, namun sistem e-budgeting di sekolah masih bersifat intranet.

\section{Pengendalian dan Pemeriksaan}

Tahapan terakhir dalam kegiatan manajemen sistem informasi dan pembiayaan adalah pengendalian dan pemeriksaan. Pengawasan dan pemeriksaan dilakukan sebagai fungsi monitoring dan evaluasi untuk mengetahui daripada tingkat keterlaksanaan dan keberhasilan pelaksanaan rencana yang telah dibuat diawal. Pengendalian dan pemeriksaan pada manajemen pembiayaan dengan sistem e-budgeting pada SMAN di Kota Yogyakarta dilakukan oleh dua pihak, yaitu 
pengendalian dan pemeriksaan oleh kepala sekolah dan dari dinas terkait (Balai DIKMEN dan DIKPORA).

Lembaga terkait (DIKPORA dan Balai DIKMEN) melakukan proses evaluasi secara menyeluruh juga meliputi daripada kinerja sekolah, evaluasi diperlukan sebagai upaya perbaikan bagi aspek apa-apa saja yang dirasa masih kurang, setelah dilakukan evaluasi lembaga ini lalu memberikan masukan dan pertimbangan untuk tindakan perbaikan kepada sekolah. Dengan evaluasi ini diharapkan kinerja sekolah kedepannya menjadi lebih baik dan dapat menjadi patokan untuk tindakan perencanaan di tahun ajaran berikutnya. Bentuk lain dari pengendalian dan pemeriksaan yang dilakukan oleh lembaga ini selain evaluasi, adalah dengan mengkoordinir serta mengawal pengelolaan keuangan di sekolah.

\section{Peran E-Budgeting dalam Transparansi dan Akuntabilitas}

Dari hasil penelitian menunjukkan bagaimana sistem e-budgeting berperan dalam meningkatkan transparansi dan akuntabilitas pembiayaan pendidikan di sekolah, yaitu: 1.) Sistem dapat meminimalisir penyelewengan dan penyalahgunaan dana; 2.) Sistem ini menuntut lebih rinci dalam pelaporan; 3.) Sistem ini bersifat online dan real time, serta adanya pemeriksaan yang dapat dilakukan secara langsung; 4.) Terdapat tahapan validasi yang bertingkat, dari proses perencanaan hingga pelaporan penggunaan anggaran; 5.) Perubahan tidak dapat dilakukan kapanpun dan terdapat cara serta tahapan tertentu bila ingin melakukan perubahan; 6.) Pembelanjaan mengacu pada $e$ katalog dan SHBJ, sehingga untuk setiap harga barang dan jasa sudah distandarkan; 7.) Meminimalkan perputaran uang secara cash atau tunai.

Pembahasan

Keberadaan sistem e-budgeting ini di sekolah terbilang masih baru karena baru diterapkan di tahun 2017. Penerapan sistem e-budgeting ini untuk digunakan di lingkungan sekolah berkaitan dengan penerapan kebijakan pengalihan kewenangan pendidikan menengah dari pemerintah kabupaten atau kota ke pemerintah provinsi. Penetapan kebijakan ini merupakan perwujudan dari tujuan desentralisasi pendidikan yakni untuk menyeragamkan pengelolaan pendidikan, khususnya jenjang SMA atau SMK antar kabupaten atau kota di wilayah provinsi (Sendhikasari, 2016).

Proses perencanaan dituangkan ke dalam dokumen yang disebut Rencana Kegiatan Dan Anggaran Sekolah (RKAS). Pengertian perencanaan kerja sekolah menurut Peraturan Menteri Pendidikan Republik Indonesia Nomor 19 tahun 2007 tentang Standar Pengelolaan Pendidikan oleh Satuan Pendidikan Dasar dan Menengah adalah merupakan rencana kerja tahunan yang disebut dengan rencana kegiatan dan anggaran sekolah (RKAS) yang akan dijadikan sebagai dasar untuk melaksanakan kegiatan yang akan dilakukan sekolah selama satu tahun kedepan. Dalam dokumen ini dituliskan apa saja kegiatan serta belanja barang dan jasa yang diubah kedalam nilai mata uang. Selanjutnya RKAS inilah yang telah disusun dan disetujui bersama, lalu akan diinput untuk diajukan melalui sistem e-budgeting. Selain itu, kemudahan lain yang diperoleh dari penggunaan sistem $e$ budgeting ini pada proses perencanaan adalah, pada sistem ini telah terdapat point-point panduan bagi sekolah tentang bagaimana dana yang diperoleh akan dianggarkan untuk apa saja.

Sekolah sebagai organisasi pendidikan dalam melaksanakan kegiatan tentu memerlukan dukungan dari berbagai pihak, seperti pemerintah, orang tua siswa, masyarakat, dan tentu warga sekolah agar dapat menjalankan tugas dan fungsinya secara baik. Dalam hal melakukan perencanaan juga memerlukan dukungan dan harus melibatkan berbagai pihak yang terkait tersebut. Hal ini dikarenakan sekolah merupakan lembaga dan juga sekaligus organisasi non-profit yang melayani masyarakat terhadap kebutuhan akan pendidikan, sehingga banyak pihak terlibat didalamnya. Dalam petunjuk teknis penyusunan kerja sekolah oleh Direktorat Pembinaan SMA (2010) ada beberapa unsur yang harus terlibat dalam penyusunan RKAS yaitu: kepala sekolah, tim kerja, dewan guru, dan komite sekolah.

Dalam pengorganisasian, pelatihan yang didapatkan oleh staf terkait di lingkungan sekolah, mereka peroleh sebelum sistem ini benar-benar diterapkan di sekolah dan dipekerjaan mereka. Pelatihan dan bimbingan yang mereka peroleh mencakup bagaimana menggunakan sistem ini secara menyeluruh. Selain karena sistem e-budgeting ini berbeda dengan sistem pengelolaan biaya 
pendidikan secara konvensional yang digunakan sebelumnya, sistem ini juga memiliki opsi atau pilihan menu yang beragam didalam sistem tersebut. Menurut Umar (2005) adapun program pelatihan dimaksudkan untuk memperbaiki penguasaan berbagai teknik dan keterampilan suatu pelaksanaan kerja tertentu. Ini melibatkan penyediaan program pengembangan dan kursus pelatihan yang cocok untuk program tersebut. Hal ini didukung pula oleh hasil penelitian Setyawan, Priyono dan Iswanaji (2017) yang menjelaskan bahwa pelatihan dapat meningkatkan keterampian SDM pengguna sistem informasi e-budgeting, sehingga dapat berimbas pada keberhasilan implementasi sistem ini. Selain itu, keberhasilan organisasi pendidikan bergantung pada kekuatan dan kualitas anggota staf. Oleh karena itu, pelatihan bagi kinerja staf sangat dibutuhkan pada pengimplementasian sistem baru pada lngkungan kerja mereka karena dapat meningkatkan efektivitas dan efisiensi untuk mencapai sasaran kerja yang diinginkan demi mencapai tujuan yang diinginkan oleh sekolah.

Penggunaan sistem informasi e-budgeting yang mana merupakan inovasi dan kebijakan baru pada dunia pendidikan dalam membantu pekerjaan manajemen pembiayaan dan melaksanakan pencatatan keuangan sekolah tentu memilki keunggulan dibanding sistem yang digunakan sebelumnya. Keunggulan sistem e-budgeting ini antara lain: 1.) Sistem informasi mendukung dan membantu dalam pengambilan keputusan. Hal ini dijelaskan oleh Davis (1995) bahwa relevansi sistem informasi dengan pengambilan keputusan adalah sistem informasi membantu melalui tahapan penyelidikan, perancangan dan pemilihan keputusan; 2.) Membantu dalam pekerjaan pengelolaan dana pendidikan, karena mempermudah dalam pencatatan, sistem yang terotomatisasi, dan sistem yang dapat diakses dimana saja dan kapan saja; 3.) Perbaikan dalam pola kerja, karena ada deadline yang membuat lebih tertib, sekolah lebih cermat dan berhati-hati dalam penggunaan dana dan pembuatan laporan; 4.) Proses administrasi dan pencairan dana lebih cepat; 5.) Sebagai sarana dan media bagi pihak terkait dalam kaitan dengan manajemen pembiayaan pendidikan (dapat melakukan proses perencanaan hingga pengawasan menggunakan sistem ini); dan 6.) Mendorong transparansi dan akuntabilitas dalam pengelolaan keuangan sekolah.

\section{SIMPULAN}

Sistem informasi e-budgeting baru diterapkan pada jenjang sekolah SMA/SMK/SLB yang berstatus Negeri, dikarenakan pada jenjang tersebut sekolah sudah bisa berlaku sebagai kuasa pemegang anggaran dan dikarenakan kebijakan pengalihan wewenang pengelolaan SMA sederajat kepada provinsi. Perencanaan (planning) dan penganggaran (budgeting) manajemen pembiayaan dengan sistem e-budgeting mengikuti alur penyusunan RKAS dan setelah itu diinput melalu sistem e-budgeting. Tahapan pengorganisasian terlaksana pada manajemen sistem informasi e-budgeting. Pada tahapan ini terjadi pengerahan staf untuk pengoperasian sistem informasi e-budgeting, jobdesk tersebut dilakukan oleh bendaharawan dan admin e-budgeting di sekolah. Pelaksanaan (actuating) dan pembukuan (accounting) sistem e-budgeting ini digunakan untuk mengelola dana APBD dan BOS (BOSDA dan BOSNAS). Fungsi pengendalian (controlling) dan pemeriksaan (auditing) pada implementasi sistem informasi e-budgeting pada SMAN di Kota Yogyakarta terdapat pengawasan melekat (waskat) yang dilakukan oleh kepala sekolah, Balai Pendidikan Menengah (DIKMEN) dan Dinas Pemuda Pendidikan dan Olahraga (DIKPORA). Keunggulan sistem e-budgeting sebagian besar berperan dalam perbaikan sistem administrasi pengelolaan dana pendidikan. Masih terdapat hambatan dalam implementas sistem e-budgeting dikarenakan sistem ini masih tergolong baru di sekolah. Sistem e-budgeting merupakan penyempurnaan daripada sistem pengelolaan dana pendidikan yang sebelumnya sudah ada di sekolah.

\section{DAFTAR PUSTAKA}

Ameen, A. B., \& Ahmad, K. (2013). A conceptual framework of financial information systems to reduce corruption. Journal of Theoretical and Applied Information Technology, 54(1), 5972. Retrieved from http://www.jatit.org/volumes/Vol54No1/9Vol54No1.pdf

Arwildayanto, A., Nina, L., \& Warni, T. S. (2017). Manajemen Keuangan dan pembiayaan pendidikan. Bandung: Widya Padjajaran. 
Anoraga, P. (2009). Manajemen bisnis. Jakarta: Rineka Cipta.

Babaei, M., \& Beikzad, J. (2013). Management information system, challenges and solutions. European Online Journal of Natural and Social Sciences, 2(3), 374-381. Retrieved from http://european-science.com/eojnss_proc/article/view/3705/1427

Creswell, J. W. (2015). Penelitian kualitatif \& desain Riset: Memilih di antara lima pendekatan ( $3^{\text {rd }}$ ed.). Yogyakarta: Pustaka Pelajar.

Davis, G. B. (1995). Kerangka dasar sistem informasi manajemen. Jakarta: Gramedia.

Direktorat Jenderal Pendidikan Dasar dan Menengah Republik Indonesia. (2015). Panduan pengembangan rencana kerja sekolah (RKS) dan rencana kegiatan dan anggaran sekolah (RKAS).

Direktorat Pembinaan Sekolah Menengah Atas Republik Indonesia. (2010). Juknis penyusunan rencana kerja sekolah.

Earthman, G, I. (2009). Planning educational facilities: What educators need to know. Maryland: Rowman \& Littlefield Education.

Gubernur Daerah Istimewa Yogyakarta. (2017). Peraturan Gubernur Daerah Istimewa Yogyakarta Nomor 72 Tahun 2017 tentang Standar Harga Barang dan Jasa Daerah.

Kementerian Pendidikan Republik Indonesia. (2007). Peraturan Kementrian Pendidikan Republik Indonesia Nomor 19 tahun 2007 tentang Standar Pengelolaan Pendidikan oleh Satuan Pendidikan Dasar dan Menengah.

Khoirunnisak, R., Arishanti, D., \& Vebrianti, D. D. (2018). Penerapan e-budgeting Pemerintah Kota Surabaya dalam mencapai good governance. UNEJ e-Proceeding, 249-256. Retrieved from https://jurnal.unej.ac.id/index.php/prosiding/article/view/6715

Lunenburg F. C., \& Ornstein, A. C. (2000). Educational administration: Concepts and practice. London: Thomas Learning Berkshire House.

Matin, M. (2014). Manajemen pembiayaan pendidikan konsep dan aplikasinya. Jakarta: Rajawali Pers.

Miles B. M., \& Huberman A., M. (1992). Analisis data kualitatif. Jakarta: UI Press.

Moleong, L. J. (2017). Metodologi penelitian kualitatif. Bandung: Remaja Rosdakarya.

Nasori, N. H. (2019). Kemandirian sekolah dalam pengelolaan pembiayaan di SD Muhammadiyah Wirobrajan 1 Yogyakarta. Seminar Nasional Pendidikan dan Call for Papers (SNDIK) I 2019. Retrieved from https://publikasiilmiah.ums.ac.id/handle/11617/11189

Pemerintah Kota Surabaya. (2017). Sistem informasi e-budgeting. Retrieved from https://ebudgeting.surabaya.go.id/new portal/

Sendhikasari, D. (2016). Pengalihan kewenangan manajemen pendidikan menengah dari kabupaten/kota ke provinsi. Info Singkat, April. Pusat Penelitian Badan Keahlian DPR RI. Retrieved from http://berkas.dpr.go.id/puslit/files/info_singkat/Info\%20Singkat-VIII-7-IP3DI-April-2016-38.pdf

Sugiyono, S. (2011). Metode penelitian pendidikan: Kuatitatif, kualitatif, PTK, R\&D. Surakarta: Fairuz.

Qadriyanti, N. L. (2013). Pengaruh partisipasi penyusunan anggaran dan akuntansi. Ilmu \& Riset Akuntansi, 2(11).

Setyawan, S., Priyono, N., \& Iswanaji, C. (2017). Development model of e-budgeting and e-reporting on the management of village fund finance. Jurnal Dinamika Akuntansi, 9(1), 92-99. doi:https://doi.org/10.15294/jda.v9i1.12000 
80 - Jurnal Akuntabilitas Manajemen Pendidikan

Terry, G., \& Rue, L. W. (2010). Dasar-dasar manajemen. Jakarta: Bumi Aksara.

Umar, H. (2005). Riset sumber daya manusia dalam organisasi. Jakarta: Gramedia Pustaka Utama.

Yin, R. K. (2010). Studi kasus: Desain dan metode. Jakarta: Rajagrafindo Persada.

Zarnelly, Z. (2017). Sistem informasi e-budgeting menggunakan pendekatan berorientasi objek (Studi kasus: UIN SUSKA Riau). Jurnal Ilmiah Rekayasa \& Manajemen Sistem Informasi, 3(1), 70-77. doi:http://dx.doi.org/10.24014/rmsi.v3i1.3449 